\title{
The Integration of Experiential Learning in Higher Education Institutions-An Assessment of the Romanian Universities
}

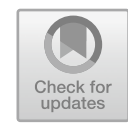

Mihaela V. Cărăuşan

\section{Introduction and Research Methodology}

The role of university education in the United Nations Sustainable Agenda has been underlined since 2002 (Johannesburg Plan). Further, Rio +20 has reinforced the need to develop a partnership with higher education institutions (HEI) to sustain an education and research system that supports local efforts for sustainable growth, and connectivity with public decision-makers. Moreover, the European Union supports the Member States in their efforts to provide education and training for all citizens"Education for everyone" (Interinstitutional Proclamation on the European Pillar of Social Rights). At the same time, the OECD offers a new vision in the Education Strategy 2030 and draws attention to some guiding principles on the future of education system and the use of specific elements to the process of experiential learning: Anticipation-Action-Reflection. In all these policy statements, the partnership between education and community is emphasised, and all call HEI to action and reflection for the integration of academic goals within the civic ones, to better connect with the society's needs. The HEI partnership for better development of the communities should start from the academic area, and it requires the entire education process to better adapt to new development areas. This adaptation process also includes the development of new learning and teaching practices, which could help HEI to engage with the policy goals mentioned by the documents above.

The current curriculum used in most of the Romanian universities is a traditional lecture-centric which, according to the literature (Karayan and Gathercoal 2005), is one of the most time-efficient and cost-efficient ways of delivering higher education. However, as Boyer (1987) emphasised, the lecture-centric approach alone is limited

M. V. Cărăuşan ( $₫)$

National University of Political Studies and Public Administration, Bucharest, Romania e-mail: mihaela.carausan@administratiepublica.eu 
in its ability to meet some of the key goals identified and commonly pursued by higher education institutions. Based on these two points of view, our paper focuses on the uptake of experiential learning at Romanian HEI, with a focus on:

1. the evaluation of obtained competences within the curricula of HEI;

2. the experience learning methods;

3. the links between academic skills (administrative sciences and management) and the 2030 labour market;

4. the capacity of HEI to implement and validate experiential learning.

Our analysis does not aim to provide a quantitative analysis against these points but to illustrate how important experiential learning is for future jobs, and to observe the degree to which today's competences in administrative sciences and management meet the requirements of the 2030 labour market.

The paper starts with a discussion on the concept of "experiential learning" (Kolb 1984; Cantor 1995; Wingfield and Black 2005) and the importance of its recognition by HEI. Experiential learning, indeed, needs to be validated at the societal and academic level. From there, the paper argues how experiential learning methods can be used to complement a lecture-centric approach at HEI.

The study presents a review of the curricula of fourteen faculties of public administration and management from Romania and explores the extent to which these include the same competences. Furthermore, it explores the challenges to which competences should answer to the new labour market requirements. We seek to answer the following research questions:

- What are the experiential and other non-formal learning instruments used by HEI?

- To what degree do educational competences respond to the labour market requirements?

- Do academics of Romanian HEI integrate the new technologies or training methods required by future generations into the teaching and training syllabuses?

To address these questions, we draw on the features identified by Kolb (1984), who presented all the necessary elements from the experiential learning cycle that HEI should examine in the change of goals process. Kolb's fundamentals helped us to identify the research terminology and to provide an overview of the particularities of the Romanian higher education system in two fields of studies: public administration and management. Because we noticed a higher level of employability of the administrative sciences alumni in the private sector and a high level of appreciation of their knowledge, the paper focuses on these two fields of studies, which compete for the same segment of the labour market. To conduct a competences analysis, we attributed one point for each Kolb's concept/action identified in each skill, the score gathered placed the field of study on the radar graphics, and we compared the results based on this. We extended the research to the new technologies: their 
role was emphasised by publications such as the World Economic Forum (2018), the Digital Economy and Society Index Report (2019), and the PWC report on the Workforce of the Future, shaping 2030 (2019). Also, our paper is granting particular attention to digital technologies, as Romania has one of the lowest levels in Europe of competencies in new technologies, with $26 \%$ of Romanians not having at least basic digital skills required in most jobs, and $51 \%$ of Romanian internet users having no software-related skills. Romania has the lowest ICT usage rates amongst internet users, second lowest-36\% (DESI Report 2019-Human Capital). Moreover, we conducted a few interviews with professors from different faculties to elicit their opinion on the use of new technologies in classrooms. We then conclude with the HEI's role in validating experiential learning.

\section{The Power of Experiential Learning}

Dewey (1938), Lewin (1952) and Piaget (1967), Cantor (1995), Fenwick (2000), Marlin-Bennett (2002), Gosen and Washbush (2004), among others, contributed to the development of experiential learning. The most referenced author is David A. Kolb (1984), who established the cycle of experiential learning focused on experience, reflection, conceptualization and action. The four innovative elements are united in grasping and transforming the learning experience (see Fig. 1). Kolb considered that several factors could influence the learning styles. Among them, we can identify those to which higher education institutions (HEI) should pay more attention: specialization, career choice, adaptive competences. The learning discovery of Kolb opened the discussion on the traditional lecture-centric learning and increased the universities' awareness of the labour market demand.

Even if experiential learning is simply defined as learning by doing (MTA Learning), Kolb (1984:38) defined as a transformative process: "the process whereby knowledge is created through the transformation of experience" or as "engagement of the education beneficiaries". Cantor later completed the second definition of Kolb with the engagement of "learner directly in the phenomena being studied" (Cantor, 1995:1). Experiential learning is the learning process by which specific adaptive methods are used for acquiring skills, competences or behaviours based on the experience of the learner and not the one of the teacher/trainer/professor. For this reason, most of the time, the person who assists the learning process must act as a facilitator, expert, evaluator and coach at the same time. 


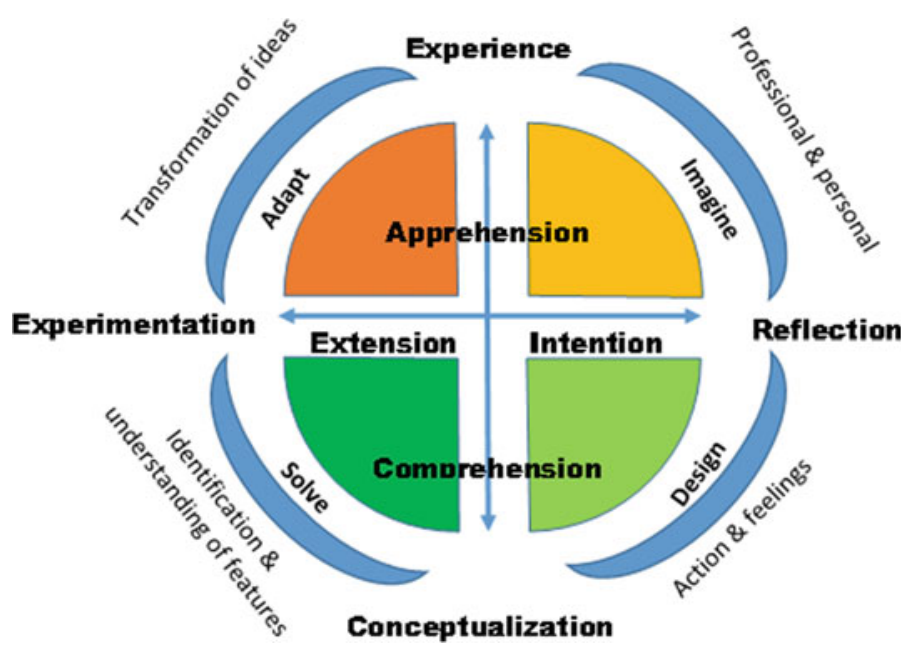

Fig. 1 Experiential learning cycle Source Adapted after Kolb (1984)

With experiential learning, HEI can tackle a wide range of skills and behaviours. The organisation of the future and the demand of workforce are not anymore anchored in the traditional learning process. In the theory of future organisations, the new type of organisations are exponential (Ismail 2014), and their needs can be fulfilled only by people who can engage with the experiential learning cycle. The impact of experiential learning in areas such as leadership, change management, virtual, crossfunctional and cultural teams, organizational effectiveness, goal setting, and time and stress management has been well acknowledged and studied in the last 20 years (Retallick and Steiner 2009; Domask 2007).

The competences provided by public administration studies need to adapt to the new technology requirements, and for doing this, HEI should invest more in experiential learning methods. These could help students understand how they can use theoretical knowledge and improve their work with the help of new technologies. In this way, we could mitigate the usual blame addressed to education provided by HEI: that "theory has nothing in common with practice". Experiential learning could include field-based coursework, internships, service learning, guest speakers, site visits. HEI need to offer graduates to acquire new skills which would give them better opportunities in the labour market - and this cannot be achieved only through passive learning in front of a computer. Kolb's idea on the role of experiential learning in the labour market was confirmed by Fink's (2003) remark on learning "significant learning is based on the engagement and promotion of active learning". Also, Brookfield (1995), Silverman and Casazza (2000) believed that learning results are obtained through critically reflective practice. Therefore, we consider that transformational change of either public or private organisations for the future can only be reached in a manner that rewards work experiences. 


\section{Future Challenges for Lecture-Centric Teaching}

Since 1978, Keeton and Tate shaped the contrast between content-story and life experience, between the linear learning and the spirally one based on practice. If in the lecture-centric (LC) system the learner is always in touch with a professor, in the experiential learning (EL) one is directly in touch with the studied realities, not just the simulated ones, and a mediator/coach takes the professor's role.

As Brown (2009:3) mentioned, experiential learning "utilize the previous experience to compile document-supported descriptions of learning outcomes acquired from the workplace and personal experiences", and the learner is directly in touch with the realities studied. The process of learning transforms a linear one-to-one into loops, and it provides a different approach to the same issue. Besides, experiential learning reduces the difference between theory and practice.

The figure below is not intended to represent all lecture-centric (LC) and experiential learning (EL) methods, but the similarities and differences between them and how they complement each other. The education system should not be categorised as experiential or not, and experiential learning does not remove the traditional lecturecentric education, the linear one. The "fish bones" representation offers a comparative perspective and emphasises the movement in the learning process (Fig. 2).

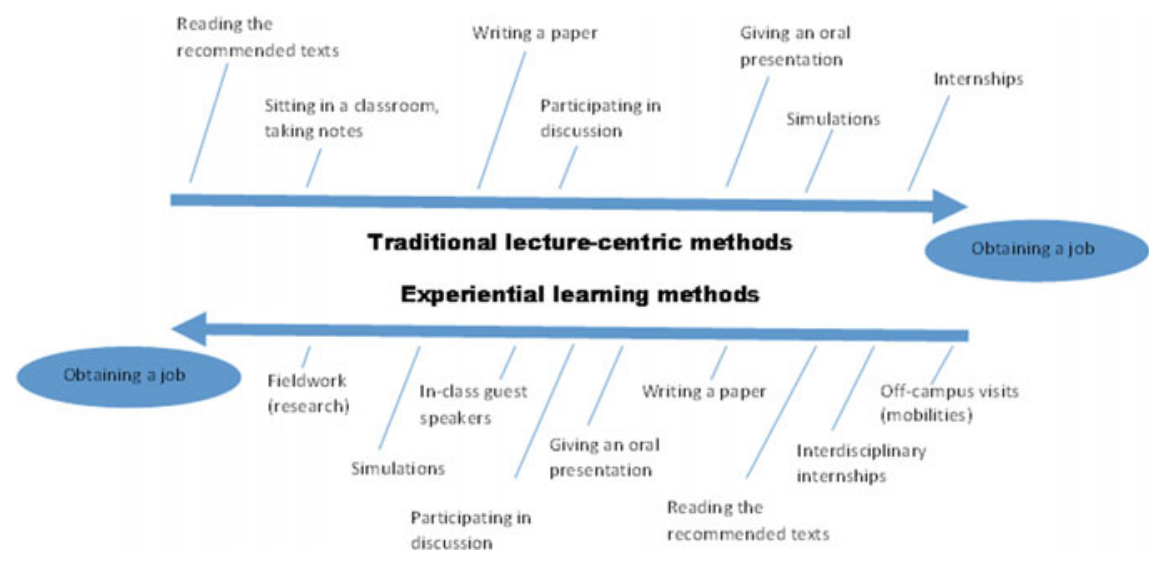

Fig. 2 A comparative spectrum of traditional lecture-centric and experiential learning methods Source Author 
All the methods mentioned on the linear learning are the most used ones in the subjects' syllabuses of fourteen faculties (see Appendix 1 with the list of universities) in administrative sciences and management. The most commonly used instruments in the syllabuses are lecture, static presentations (PowerPoint), students' presentations, open discussions, case studies or simulations of possible situations identified by professors based on their experience. While syllabuses refer to formal learning methods such as traditional lecture-centric methods, they do not include other methods associated with the experiential learning process, such as non-formal ${ }^{1}$ (fishbowl, green card, forum theatre, photo-voice, debates, bees' nest, story-telling and others) and informal instruments (volunteering activities, seminars/conferences/guest speakers, job shadowing, and social media engagement). However, the core aim of future HEI, as it concerns teaching and learning, should be to combine multiple forms of educational approaches, all of which are experiential in one way or another, and to directly expose students to actual practices in their respective fields through different methods. The students are required to present their study plan, and the faculty members facilitate/assist him/her in the process.

\section{Educational and/Vs Professional Competences}

Experiential learning is a powerful way to help people identify changes required to their skills, attitudes and behaviours (MTA) to access professional competences. If the educational competences are those acquired in the process of learning different subjects, the professional ones denote the capability to perform professional duties, generally, and with acceptable quality. Graduates' educational competences are described in the Diploma Supplement of Romanian HEI as attitudes, skills and knowledge, which they can apply for successful working. As it concerns the professional competences, e.g. the ones for civil servants (graduates of public administration), include not only their theoretical level of knowledge, ability to use specific terms and concepts, but also knowledge and skills in different fields such as psychology, law, management, economics, sociology, and personal qualities (being decisive, dedicated, and hard-working). All these help them to reach a certain proficiency level. Starting from Simonton's (2003:230) idea of competence as "any acquired skill or knowledge that constitutes an essential component for performance or achievement in a given domain", the question: "competent for (doing) what?" is essential to any HEI.

Since 2000, the European Commission (Memorandum of Lifelong Learning) stated that learning is "valued" in formal, non-formal or informal settings. It is important to note that Lifelong Learning (LLL) also encompasses training or preparation for the world of work, adaptation, prevention, promotion, maintaining and providing skills, abilities and knowledge necessary to the labour market. Experiential learning

\footnotetext{
${ }^{1}$ For a detailed list of non-formal methods, please access https://www.nonformalii.ro/ for the ones used in Romania or https://www.salto-youth.net/tools/toolbox/ for the European ones.
} 
values learning in a different setting and can be the solution that assesses the professional and personal experiences and can bring closer theory and practice, in any field of study.

Experiential learning could be better valued at the master, postgraduate studies or lifelong-learning (LLL) programmes. LLL reflects societal changes of a structural and socio-economic nature and governments' concern about creating a new workforce, able to adapt to rapidly changing work patterns and the demands of a knowledge-based society (Pouget and Osborne 2004, 60).

The contribution of experiential learning to educational goals is difficult to prove, and quantitative assessments are not well emphasized in academic literature yet (Lowenthal and Sosland 2007; Wingfield and Black 2005; Gosen and Washbush 2004). Even so, its importance in the learning process of future generations was highlighted in the OECD Learning Compass 2030. The OECD framework offers a broad vision of the students' future competences and develops a common language and understanding that is globally relevant and informed.

Jessup's (1991:26) distinction between job competence and professional competence is the one that helps us to understand better "the concrete experience" of Kolb. Job competence refers to the job attributions 'limited to a particular role in a particular company', and professional competence refers to the repertoire of skills, abilities, knowledge that a person owns following education and/or experience learning. The necessary steps to implement experiential learning in HEI to reduce the mismatching with the labour market requirements were not yet determined. The word competence is somewhat fraught, if inescapable, in the theoretical and academic landscape against which people's experience is accredited or validated (Pouget \& Osborne, 2004:57).

In our research, we have noticed that the skills/competences identified in the Diploma Supplement of fourteen faculties from nine Romanian Universities differ, to some extent, from one to another.

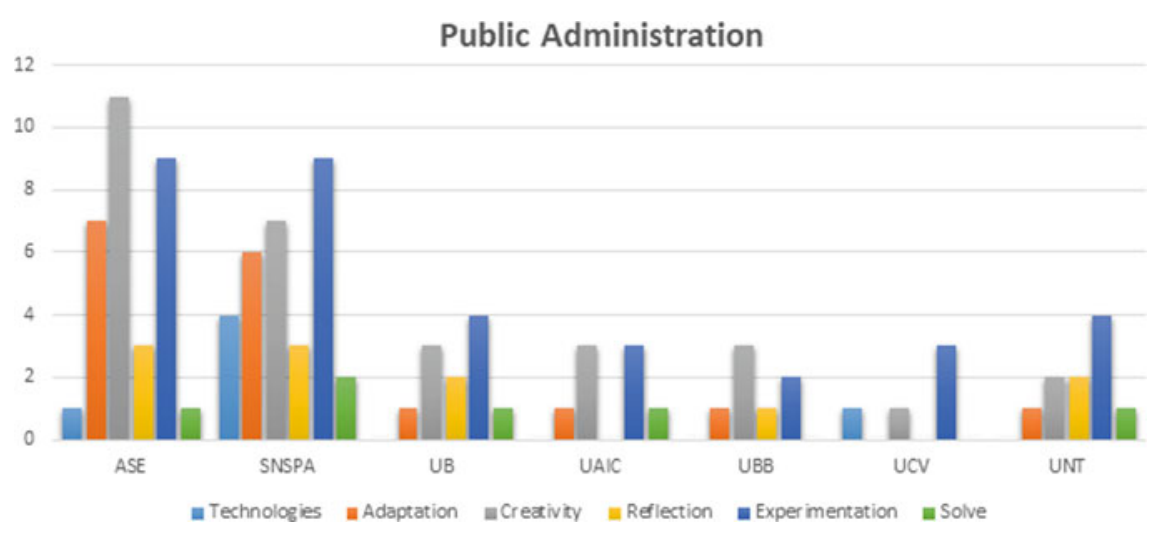

Fig. 3 Comparative study of the score gained by each Faculty of Public Administration 


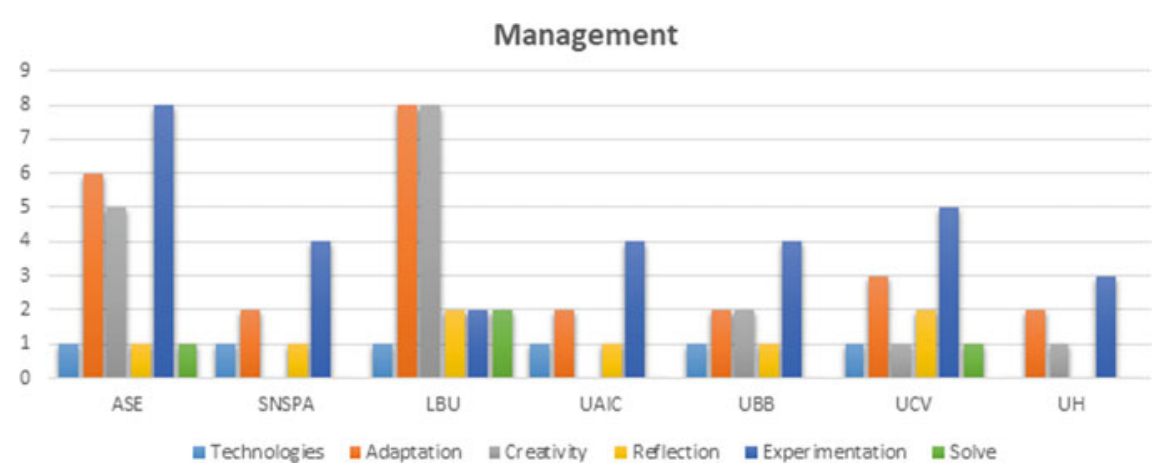

Fig. 4 Comparative study of the score gained by each Faculty in Management

According to the Romanian Agency for Quality Assurance in Higher Education (ARACIS), each faculty has the autonomy to establish professional and transversal competences for its study programmes while the core subjects, for each field of study, are set by the accreditation standards. Furthermore, faculties experience different capacities in responding to the new requirements of the employment market (see Figs. 3, 4 and 6). Consequently, the autonomy level of each faculty to establish different competences for the same subject is very high, even if they train their graduates for the same jobs.

\section{Validation of Experiential Learning in Romanian Higher Education Institutions}

Recognition of experiential learning or any other tools used in the educational process is not possible according to the evaluation criteria of ARACIS. Active learning does not belong to any standard evaluated by the Agency, and the level of promotability of one subject or the entire study programme is not assessed in connection with this. Within Kolb's learning cycle, we identify some elements such as adaptation, design, reflection or experimentation, but none of them is mentioned in the Romanian accreditation standards. This concerns us because Romania has one of the highest dropout rates for tertiary education among European Union countries (5th place, with $15.7 \%)$.

Moreover, the most frequently awarded degree in 2017 was management and administration; across the EU-28, some 203,000 people in this field graduated with a bachelor's degree and 150, 000 with a master's degree. These numbers are higher than the equivalent share of tertiary education students still in the process of studying within these fields. ${ }^{2}$

An overview of the curricula of the fourteen faculties on administrative sciences and management indicated that the educational skills/competences mentioned in the diploma supplement do not include advanced skills on new technologies, the skills

${ }^{2}$ The data are from EUROSTAT-Early leavers from education and training, 2017, accessed on https://ec.europa.eu/eurostat/statistics-explained/index.php?title=Tertiary_education_statistics. 
of adaptation or creativity in the decision making process. Based on the research's results, presented in Figs. 3 and 4, each faculty reaches a different degree of development for each educational skills/competences required by the future employment market. Taking these into account and because we could not identify the elements of Kolb's system, we extended the research to different activities and concepts based on the causality connection. In this way, we have determined for advanced skills on new technologies concepts like technologies, data or databases use. For Kolb's idea of adaptation, we started from the idea that this is a process of transformation of knowledge into actions to gain experience, and we searched for operations such as evaluation or assessment.

Furthermore, we related creativity with processes like design, development, and plan of action or interpretation. Likewise, in our quest to identify also the other two specific competences-reflection and experimentation, which were also not identified, we extended the research for experimentation to synonyms' concepts like analyse, measure, utilization, use, apply, and for reflection to observation or point of view. For each concept/action identified in each skill, we attributed one point, the gathered score placed the field of study on the radar graphics, and based on this, we could compare the results (see Figs. 5, 6 and 7).

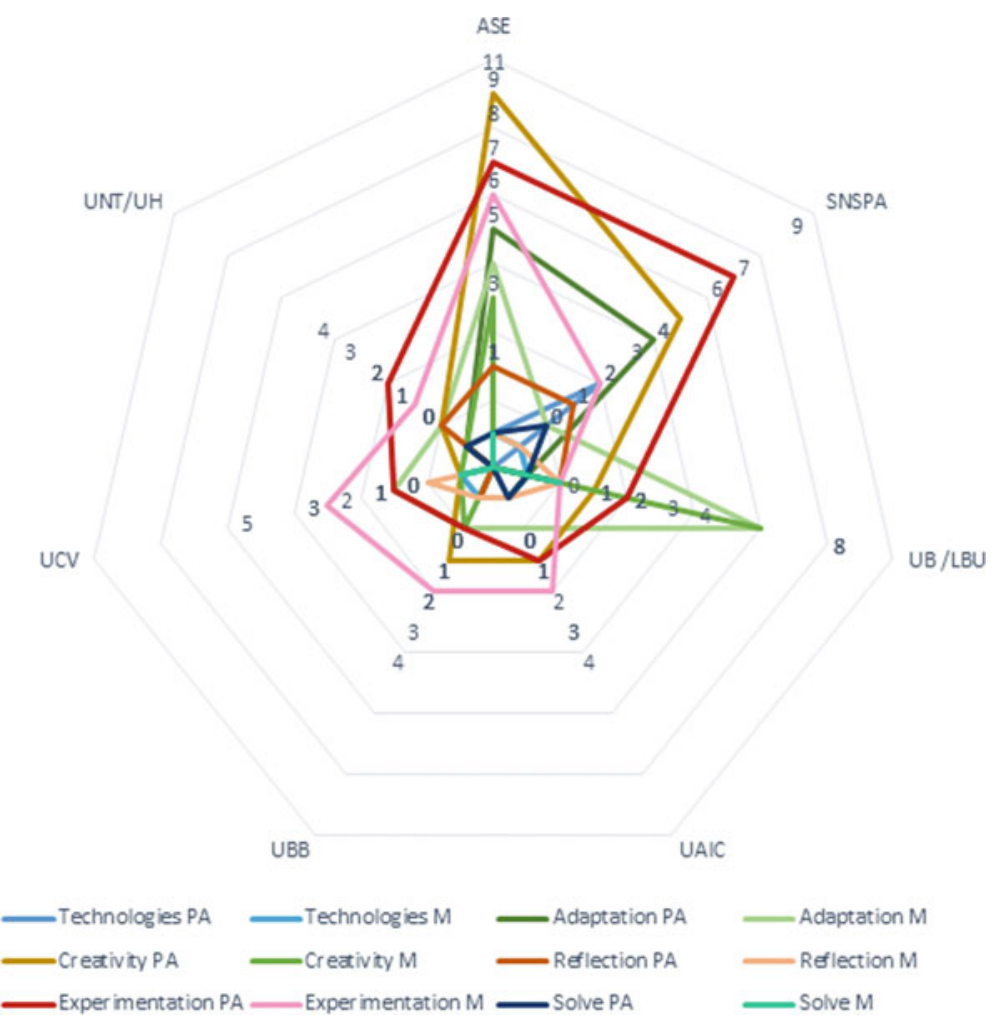

Fig. 5 Comparative study of the score gained by each University in both fields of studies 

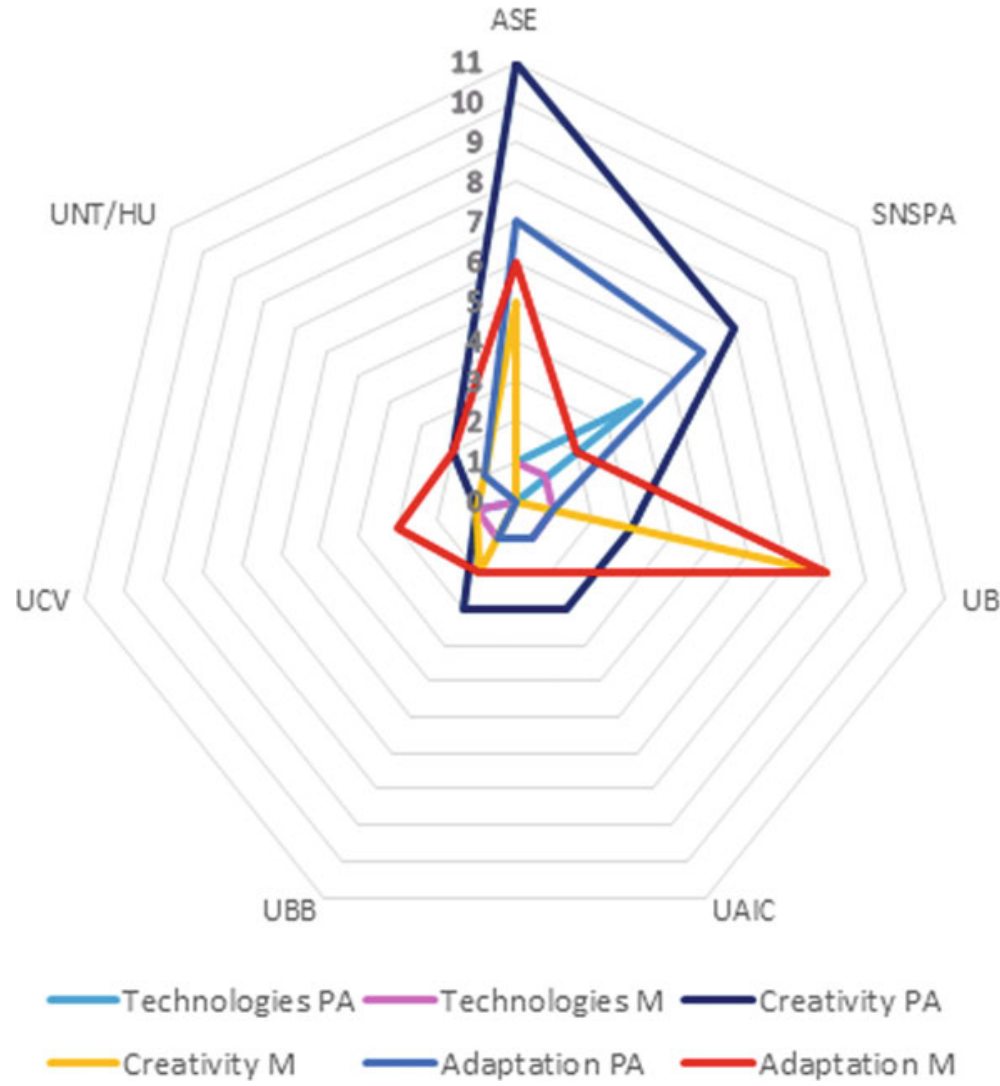

Fig. 6 Comparative study of the score gained by each University in both fields of studies on the necessary skills for the future employment market (new technologies, adaptation, creativity)

In this comparison, we can observe that, in both fields of studies, none of the reviewed universities has a constant development of the concepts used in experiential learning. Also, the highest level reached in one field of study at one university is not at the same level for the other, e.g. for creativity in public administration, the Bucharest University of Economic Studies (ASE) obtained 11 points, but for management only 5. Further, we can observe that public administration is better prepared to use concepts related to experiential learning; the average score is with 0.33 higher than the one for management.

We had to extend the research to the related concepts because, for example, the most common competence related to new technologies is: "the ability to use modern informatics technology for editing and processing information and accessing databases necessary". This competence is given by the IT subject, which is mandatory in public administration curricula, even so not all the programs have it (see Fig. 7). With the results obtained in Fig. 5 and the following ones, we can confirm the unreadiness of Romanian universities to answer the labour market requirements, especially on new technologies. 


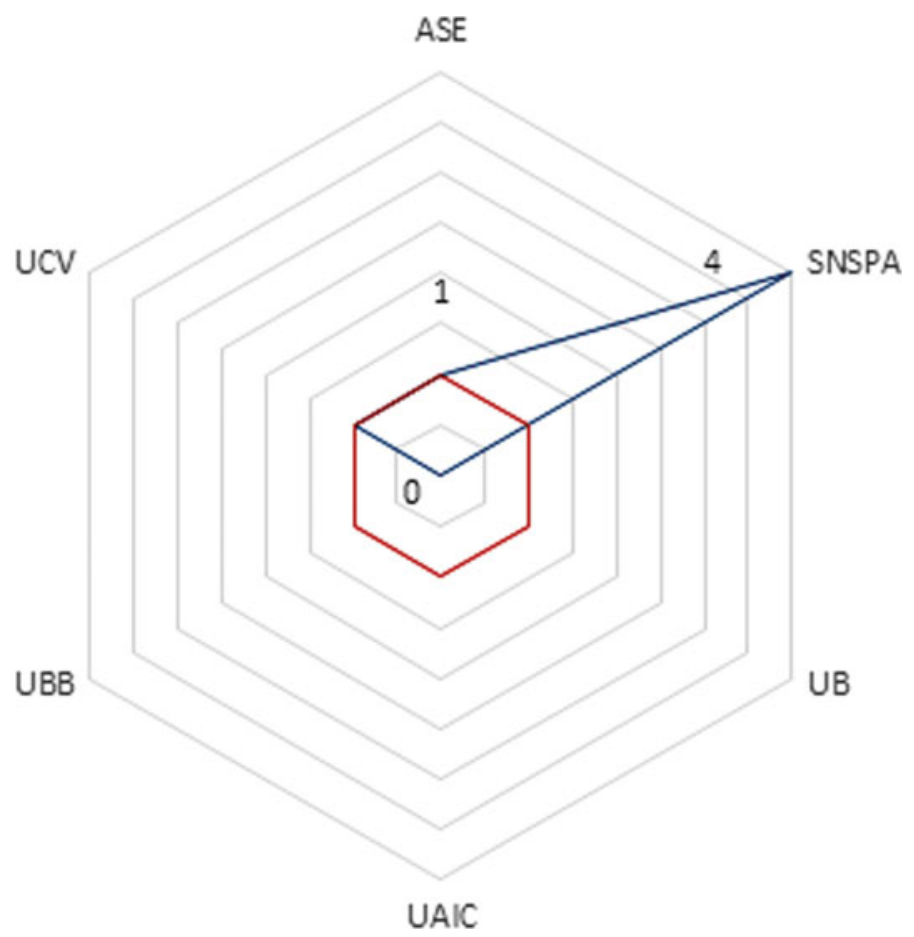

Fig. 7 Comparative study of each University in both fields of studies on the new technologies

From all the competences in the two domains, administrative sciences and management, we selected the one on new technologies because is the most practical one, and its organisation can be off the campus and based on non-formal or experiential tools. None of the professors uses computers in classes for the learning process, except the IT and the final research project. Moreover, in subjects' syllabuses, requirements are limited to a computer and video-projector for the teachers' presentations (PowerPoint), white/blackboards or flipcharts and writing instruments. In the professors' interviews, some answers are eloquent for the use of new technologies in HEI: e.g. "the computers' room is closed, only the guy from IT has the key" or "the IT professor has its office in the computers' room, so we cannot enter". Besides, on the technical abilities, OECD (2018) mentioned Romania within the countries with a high degree of mismatch between educational competences and job ones $(30 \%)$. This mismatch could be a real threat for graduates, taking into account the job requirements of future exponential organisations. 


\section{Concluding Remarks}

Experiential learning is about experiences in action and not just knowledge. All the Romanian HEI praise on their web page the experience of their professors and/or practitioners, but none of them presents the methods used, the ones that differentiate them from the others. Moreover, no admission web page from Romanian HEI indicates the goals, the educational competences or the learning outcomes. The results obtained in our research did not provide a clear answer to our research question about the readiness of the academics to accept experiential learning methods as a pillar of the learning process. For a substantiated answer to this, we would need to study further the academics' response to experiential learning in these two fields of study-although a number of them already mentioned that they had no request to use experiential learning, and have no training to do so.

Experiential learning in Romania faces challenges that other educational systems may not face. Implementing experiential learning needs investments to overpass the current reluctance of professors. As the review of the subjects' syllabuses and literature in education science demonstrated, the lecture-centric method may appear as the most time-efficient one for those who teach. Working towards student learning outside the classroom requires more time for preparation and training. Currently, the most commonly used methods are the static ones, and even if some of them could be used together with experiential learning methods, none of the syllabuses presents them in this way.

Because the labour market perspective starts with the new technological realities and moves forward in demanding professional competencies, the Romanian educational system should learn how to provide them. This high degree of imbalance between the required job competencies and the educational competences should force HEI to act and to pay more attention to the goals they want to accomplish. Moreover, they have to think more about the results-educating professional alumni.

\section{Appendix 1}

See Table 1. 
Table 1 The list of studied Universities and Faculties

\begin{tabular}{|c|c|c|c|}
\hline No. & University & Acronym & Faculty/Field of study \\
\hline 1 & $\begin{array}{l}\text { The Bucharest University of } \\
\text { Economic Studies, } \\
\text { Bucharest }\end{array}$ & ASE & $\begin{array}{l}\text { Faculty of Administration and Public Manage- } \\
\text { ment, Public administration/Bachelor in public } \\
\text { administration } \\
\text { Faculty of Management, } \\
\text { Management/Bachelor in Economics }\end{array}$ \\
\hline 2 & $\begin{array}{l}\text { National University of } \\
\text { Political Studies and Public } \\
\text { Administration, Bucharest }\end{array}$ & SNSPA & $\begin{array}{l}\text { Faculty of Public Administration, Public } \\
\text { administration/B.A. in Administrative Sci- } \\
\text { ences } \\
\text { Faculty of Management/BA in Economics }\end{array}$ \\
\hline 3 & $\begin{array}{l}\text { "Alexandru Ioan Cuza" } \\
\text { University of Iasi }\end{array}$ & UAIC & $\begin{array}{l}\text { Faculty of Economics and Business Admin- } \\
\text { istration, Public administration/Bachelor of } \\
\text { Administrative Sciences } \\
\text { Faculty of Economics and Business } \\
\text { Administration, Management/Bachelor of } \\
\text { Economics }\end{array}$ \\
\hline 4 & $\begin{array}{l}\text { Babeş-Bolyai University of } \\
\text { Cluj-Napoca }\end{array}$ & UBB & $\begin{array}{l}\text { Faculty of Political, Administrative And Com- } \\
\text { munication Sciences, Faculty of Political, } \\
\text { Administrative and Communication Sciences } \\
\text { Public Administration/Bachelor in Adminis- } \\
\text { tration Sciences } \\
\text { Faculty of Economics and Business } \\
\text { Administration, Management/Bachelor in } \\
\text { Economics (in Romanian or English) }\end{array}$ \\
\hline 5 & University of Craiova & $\mathrm{UCV}$ & $\begin{array}{l}\text { Faculty of Law and Social Sciences, Public } \\
\text { Administration/Graduate in administrative sci- } \\
\text { ences } \\
\text { Faculty of Economics and Business } \\
\text { administration, Management/Bachelor in } \\
\text { Economic Science }\end{array}$ \\
\hline 6 & University of Bucharest & UB & $\begin{array}{l}\text { Faculty of Business and Administration, } \\
\text { Public Administration/Bachelor of } \\
\text { Administrative Sciences }\end{array}$ \\
\hline 7 & $\begin{array}{l}\text { "Lucian Blaga" University } \\
\text { of Sibiu }\end{array}$ & LBU & $\begin{array}{l}\text { Faculty of Economic Sciences, } \\
\text { Management/Bachelor of Economic Sciences }\end{array}$ \\
\hline 8 & $\begin{array}{l}\text { "Nicolae Titulescu" } \\
\text { University of Bucharest }\end{array}$ & UNT & $\begin{array}{l}\text { The Faculty of Social and Administrative } \\
\text { Sciences, Public Administration/Bachelor of } \\
\text { Administrative Sciences }\end{array}$ \\
\hline 9 & $\begin{array}{l}\text { Hyperion University from } \\
\text { Bucharest }\end{array}$ & $\mathrm{UH}$ & $\begin{array}{l}\text { Faculty of Economic Sciences, Management/ } \\
\text { Degree in Economics Sciences }\end{array}$ \\
\hline
\end{tabular}




\section{References}

Boyer, D. (1987). College: The Undergraduate Experience in America. Harper \& Rowe, NewYork, NY.

Brookfield, S.D. (1995). Becoming a critically reflective teacher. San Francisco, CA: Jossey-Bass.

Brown, M. (2009). Reconceptualising outdoor adventure education: activity in search of an appropriate theory. Australian Journal of Outdoor Education, 13(2), 3-13.

Cantor, J.A. (1995). Experiential Learning in Higher Education: Linking Classroom and Community, ASHE-ERIC Higher Education Report No. 7.

Dewey, J. (1938). Experience and Education. New York: Macmillan.

Digital Economy and Society Index Report (2019). Human capital, accessed on https://ec.europa. eu/digital-single-market/en/desi

European Commission Memorandum of 30 October 2000 on lifelong learning SEC(2000) 1832 final.

European Commission, Digital Economy and Society Index Report (DESI), 2019, Human Capital Digital Inclusion and Skills Report accessed on https://ec.europa.eu/newsroom/dae/document. cfm?doc_id=59976.

Fenwick, T.J. (2000). Expanding conceptions of experiential learning: a review of the five contemporary perspectives of cognition. Adult Education Quarterly, 50(4), 243-72.

Fink, L.D. (2003). Creating significant learning experiences: An integrated approach to designing college courses. San Francisco, CA: Jossey-Bass.

Gosen, J. \& Washbush, J. (2004). A review of scholarship on assessing experiential learning effectiveness. Simulation and Gaming, 35(2), 270-93.

Interinstitutional Proclamation on the European Pillar of Social Rights (2017/C 428/09), 2017, art. 1, accessed on https://eur-lex.europa.eu/legal-content/EN/TXT/PDF/?uri=CELEX: 32017C1213(01)\&from=EN

Jessup, G. (1991). Outcomes: NVQs and the emerging model of education and training. London: Falmer Press.

Joseph J. Domask. (2007). Achieving goals in higher education. An experiential approach to sustainability studies, International Journal of Sustainability in Higher Education, Vol. 8(1), 53-68.

Karayan, S. \& Gathercoal, P. (2005). Assessing service-learning in teacher education. Teacher Education Quarterly, 32(3), 79-92.

Keeton, Morris T \& Tate, Pamela J (1978). Learning by experience-what, why, how. Jossey-Bass, San Francisco

Kolb, D.A. (1984). Experiential Learning: Experience as the Source of Learning and development, Prentice-Hall, Englewood Cliffs, NJ.

Lewin, K.. (1952). Field Theory in the Social Sciences: Selected Theoretical Papers. London: Tavistock.

Lowenthal, D. \& Sosland, J. (2007). Making the grade: how a semester in Washington may influence future academic performance?. The Journal of Political Science Education, 3(2)(in press).

Marlin-Bennett, R. (2002). Linking experiential learning and classroom education: lessons learned from the American University - Amnesty International USA Summer Institute on Human Rights. International Studies Perspectives, 3, 384-95.

Mireille Pouget \& Michael Osborne. (2004). Accreditation or validation of prior experiential learning: knowledge and savoirs in France - a different perspective? Studies in Continuing Education, 26(1) March.

MTA Learning, What is Experiential Learning? Accessed on https://www.experientiallearning.org/ about-mta/what-is-experiential-learning/

OECD, Learning Compass 2030, in brief, accessed on https://www.oecd.org/education/2030project/teaching-and-learning/learning/learning-compass-2030/

OECD, Skills for jobs, Romania country note (2018). accessed on https://www. oecdskillsforjobsdatabase.org/data/country_notes/Romania\%20country\%20note.pdf 
Piaget, Jean. (1967). The Mental Development of the Child. In D. Elkind. (Ed.), Six Psychological Studies. New York: Vintage Books.

Retallick, M. S., \& Steiner, C. (2009). A Model for Implementing a College-wide Experiential Learning Program in Higher Education, NACTA Journal, March, 2-6.

Salim Ismail, Michael S. Malone \& Yuri Van Geest. (2014). Exponential organisations, Diversion Books, pp. 51-84.

Silverman, S.L. \& M.E. Casazza. (2000). Learning and development. San Francisco, CA: JosseyBass.

Simonton, D. K. (2003). Expertise, Competence, and Creative Ability: The Perplexing Complexities. In R. J. Sternberg \& E. L. Grigorenko (Eds.), The Psychology of Abilities, Competencies, and Expertise (pp. 213-239). New York: Cambridge University Press.

Wingfield, S.S. \& Black, G. (2005). Active versus passive course designs: the impact on student outcomes, Journal of Education for Business, 81(2), 119-23.

World Economic Forum (2018). The Future of Jobs Report, accessed on https://www.weforum.org/ reports/the-future-of-jobs-report-2018

World Summit on Sustainable Development (WSSD), Johannesburg Summit, (2002). Plan of Implementation of the WSSD, para. 105(a), 108, 117 (b), 124 (b), accessed on https://www.un.org/esa/ sustdev/documents/WSSD_POI_PD/English/WSSD_PlanImpl.pdf.

United Nations Conference on Sustainable Development, Rio+20, 2012, Future We Want - Outcome document, A/RES/66/288, para. 229-235 and 272, accessed on https://sustainabledevelopment. un.org/rio20/futurewewant

Open Access This chapter is licensed under the terms of the Creative Commons Attribution 4.0 International License (http://creativecommons.org/licenses/by/4.0/), which permits use, sharing, adaptation, distribution and reproduction in any medium or format, as long as you give appropriate credit to the original author(s) and the source, provide a link to the Creative Commons license and indicate if changes were made.

The images or other third party material in this chapter are included in the chapter's Creative Commons license, unless indicated otherwise in a credit line to the material. If material is not included in the chapter's Creative Commons license and your intended use is not permitted by statutory regulation or exceeds the permitted use, you will need to obtain permission directly from the copyright holder.

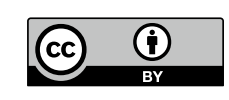

